\title{
The impact of standard preparation practice on the runoff and soil erosion rates under laboratory conditions
}

\author{
Abdulvahed Khaledi Darvishan, Vafa Homayounfar, and Seyed Hamidreza Sadeghi \\ Department of Watershed Management Engineering, Faculty of Natural Resources, Tarbiat Modares University, \\ P.O. Box 46417-76489, Noor, Iran \\ Correspondence to: Abdulvahed Khaledi Darvishan (a.khaledi@modares.ac.ir)
}

Received: 26 January 2015 - Published in Solid Earth Discuss.: 3 March 2015

Revised: 17 August 2016 - Accepted: 19 August 2016 - Published: 6 September 2016

\begin{abstract}
The use of laboratory methods in soil erosion studies, rainfall simulation experiments, Gerlach troughs, and other measurements such as ring infiltrometer has been recently considered more and more because of many advantages in controlling rainfall properties and high accuracy of sampling and measurements. However, different stages of soil removal, transfer, preparation and placement in laboratory plots cause significant changes in soil structure and, subsequently, the results of runoff, sediment concentration and soil loss. Knowing the rate of changes in sediment concentration and soil loss variables with respect to the soil preparation for laboratory studies is therefore inevitable to generalize the laboratory results to field conditions. However, there has been little attention given to evaluate the effects of soil preparation on sediment variables. The present study was therefore conducted to compare sediment concentration and soil loss in natural and prepared soil. To achieve the study purposes, 18 field $1 \times 1 \mathrm{~m}$ plots were adopted in an $18 \%$ gradient slope with sandy-clay-loam soil in the Kojour watershed, northern Iran. A portable rainfall simulator was then used to simulate rainfall events using one or two nozzles of BEX: 3/8 S24W for various rainfall intensities with a constant height of $3 \mathrm{~m}$ above the soil surface. Three rainfall intensities of 40,60 and $80 \mathrm{~mm} \mathrm{~h}^{-1}$ were simulated on both prepared and natural soil treatments with three replications. The sediment concentration and soil loss at five 3 min intervals after time to runoff were then measured. The results showed the significant increasing effects of soil preparation $(p \leq 0.01)$ on the average sediment concentration and soil loss. The increasing rates of runoff coefficient, sediment concentration and soil loss due to the study soil preparation method for laboratory soil ero-
\end{abstract}

sion plots were 179,183 and $1050 \%(2.79,2.83$ and 11.50 times), respectively.

\section{Introduction}

Soil, as one of the valuable natural resources, is nonrenewable at short timescales and should be studied with a multidisciplinary perspective (Brevik et al., 2015). The soil system is the key to determining the sustainability of the Earth system. It controls the hydrological, erosional, biological and geochemical cycles and also contributes to the resources, goods and services given to the humankind (Keesstra et al., 2016). Soil erosion is a result of the interaction of several factors which vary in space and time (Cerdà, 1998b; Le Bissonnais et al., 2002; Borrelli et al., 2015; Martin-Moreno et al., 2016; Prosdocimi et al., 2016). Study of soil erosion and sediment yield in the watershed is one of the basic necessities to achieve integrated land management and soil and water conservation. The identification and quantification of the hydrological properties and processes that induce runoff and soil erosion are necessary to determine the amount of soil erosion (Cerdà et al., 1997; Cerdà, 1999; Ramos et al., 2000; Iserloh et al., 2012, 2013; León et al., 2013; Martínez-Murillo et al., 2013). Although the measurement of runoff and sediment using rainfall simulators can be performed in the laboratory (Gholami et al., 2014; Bochet, 2015; Rodrigo Comino et al., 2015b, 2016a; Sadeghi et al., 2015) and field conditions (Cerdà et al., 2009a; Lieskovský and Kenderessy, 2014; Biswas et al., 2015; Bochet, 2015; Pereira et al., 2015; Ochoa et al., 2016; Rodrigo Comino et al., 2016), field measurements are usually costly and time-consuming work. In addi- 


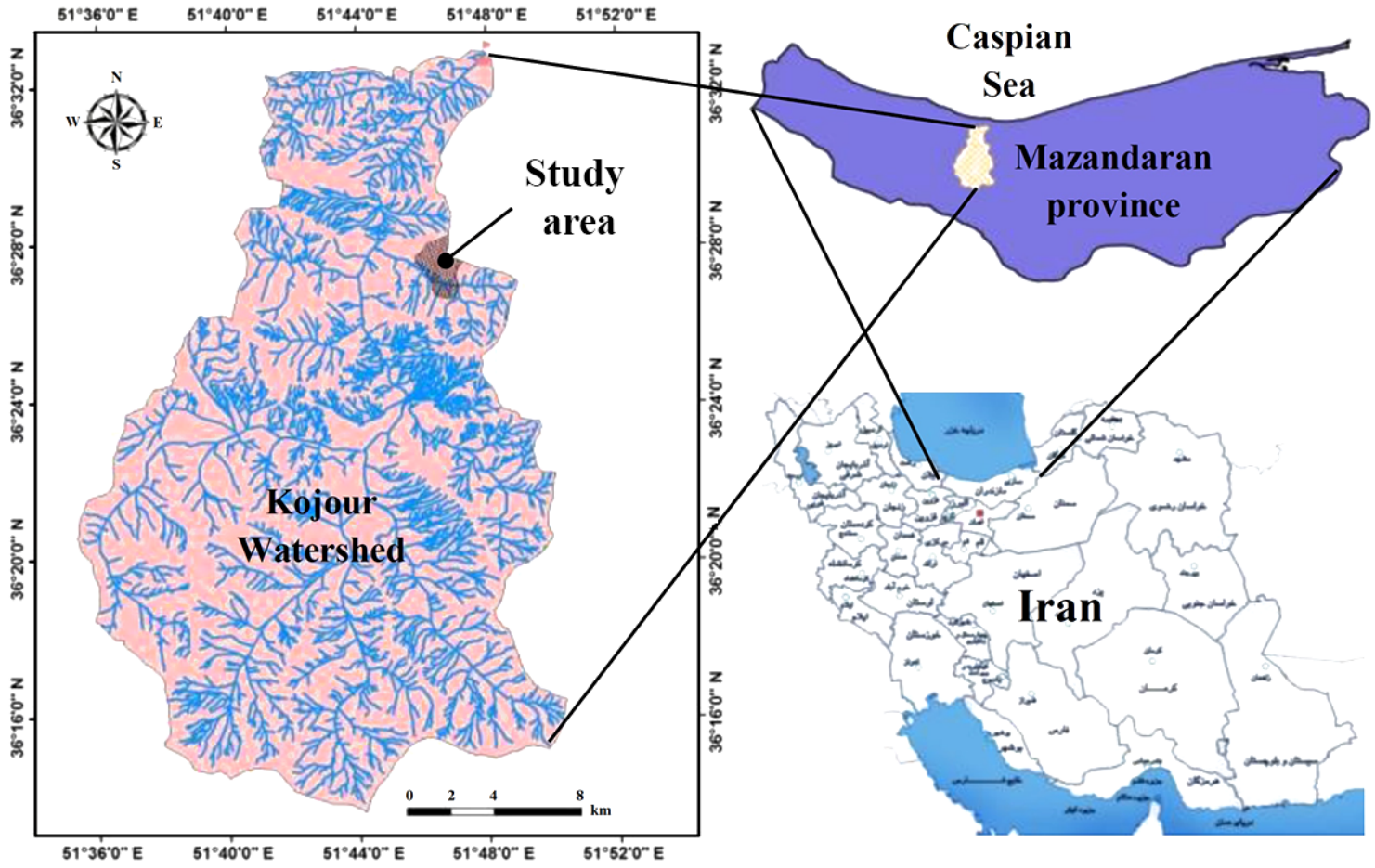

Figure 1. Location of the study area in Kojour watershed, Mazandaran Province, Iran.

tion, different methods of measuring runoff and erosion may lead to non-identical results that are not necessarily related to specific effects on studied variables (Cerdà et al., 2009b, 2013; Selkimäki et al., 2016; Zhao et al., 2016). Nowadays, the use of rainfall simulators in laboratory and field studies is considered more and more because of their ability to control the intensity and duration of rainfall, which leads to an increase in the accuracy of data (Sadeghi et al., 2015; Davudirad et al., 2016). On the other hand, measuring runoff and soil loss at the plot scale has been of crucial importance from the beginning of the soil erosion research (Licznar and Nearing, 2003). The limitations of laboratory studies of soil erosion leads to a lack of confidence especially when the aim of research is to study some important factors affecting erosion (Toy et al., 2002), which may because of soil disturbance in the laboratory. Although various methods for soil preparation have been proposed to perform laboratory soil erosion research (Ekwue, 1991; Romkens et al., 2001; Hawke et al., 2006; Ekwue and Harrilal, 2010; Kukal and Sarkar, 2010), all these methods have one major goal - that the soil samples are placed in the experimental plots as homogeneous as possible (Hawke et al., 2006). Changes in the soil during sampling, transportation and various stages of preparation include air-drying, passing through a sieve, soil moisture content during the preparation process. Finally, compaction to increase the bulk density of the soil surface by roller may influence the results of runoff and erosion. For example, the significant effect of soil characteristics such as small relief and aggregate shape on the amount and spatial pattern of runoff (Kirkby, 2001) and of surface roughness on runoff and erosion (Gomez and Nearing, 2005), which have been approved before, can all be created or weakened and intensified by rolling the soil surface. Tillage, as one of the most important human factors that leads to soil disturbance, is also a way to disturb the soil and will create higher erosion rates (Novara et al., 2011, 2016; Cao et al., 2015; Ligonja et al., 2015; Nanko et al., 2015; Ochoa-Cueva et al., 2015; Sadeghi et al., 2015). This also occurs when the soil is disturbed by changes in crops (Zhang et al., 2015). Nevertheless, the textural and structural changes during soil preparation for experimental studies of erosion may not be the same with those in preparation for agriculture, forestry or gardening purposes because of many differences in the method of soil preparation. Despite the higher costs, effort, soil disturbances, etc., application of laboratory plots has been justified sometimes instead of natural plots because of advantages in controlling rainfall properties and high accuracy of sampling and measurements.

The present research has been therefore conducted to evaluate the effects of soil preparation for experimental studies on runoff and soil erosion. The results of present research can hopefully be used to generalize the results of laboratory studies of soil erosion to natural conditions more accurately. 


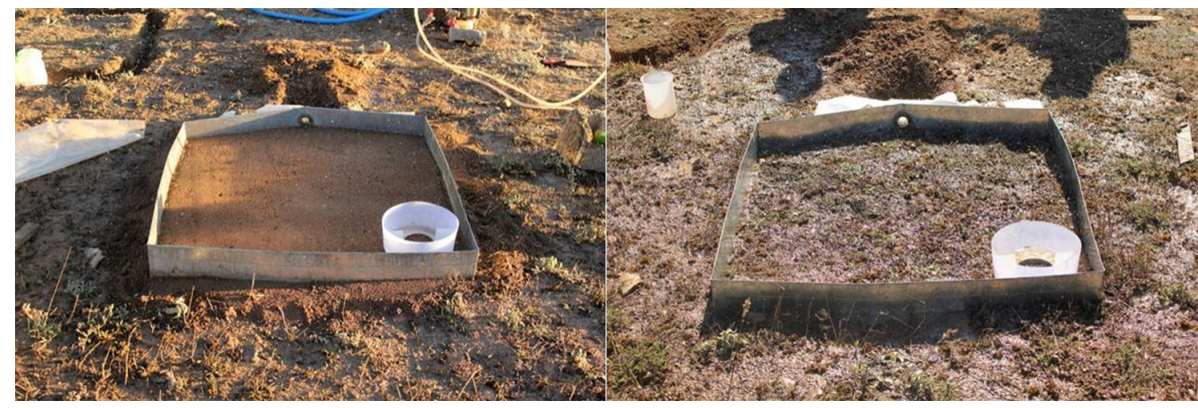

Figure 2. Views of the plots in both soil treatments; before soil preparation (right) and after soil preparation (left).

\section{Materials and methods}

\subsection{Study area}

The field experiments were conducted in a south slope with sandy-clay-loam soil located in the longitude and latitude of $36^{\circ} 27^{\prime} 15^{\prime \prime} \mathrm{N}$ and $51^{\circ} 46^{\prime} 27^{\prime \prime} \mathrm{E}$ and the altitude of $1665 \mathrm{~m}$ in the vicinity of Kodir village in Educational and Research Forest Watershed of Tarbiat Modares University, in the north of Iran (Fig. 1). The degree of the slope at the experiments site was about $18 \%$. The amounts of organic matter, $\mathrm{pH}$ and EC (Electrical Conductivity) of the studied soil were $2.2 \%$, 7.9 and $0.1576 \mathrm{~d} \mathrm{~S} \mathrm{~m}^{-1}$ respectively.

\subsection{Installation and preparation of plots}

The top $20 \mathrm{~cm}$ layer of the soil was collected for soil preparation using Kukal and Sarkar (2011) method with some modifications to maintain aggregate structure (Khaledi Darvishan et al., 2012, 2014). The collected soil was air-dried to the optimum soil moisture content (Fox and Bryan, 1999). All plant residues and pebbles were removed from the soil (Agassi and Bradford, 1999), and finally the soil was passed through a $8.0 \mathrm{~mm}$ sieve (Ekwue and Harrilal, 2010; Defersha et al., 2011; Khaledi Darvishan et al., 2014). The prepared soil was then transferred into the nine plots with the depth of about $15 \mathrm{~cm}$. Because of the effects of soil bulk density on soil resistance against rain drops and runoff (Luk, 1985; Cerdà, 2002), a PVC pipe with diameter of $10 \mathrm{~cm}$ and filled with a mixture of sand and cement as a roller was used to compact the soil to achieve the natural bulk density of the soil. The other nine plots were placed on the soil in natural condition, and all plant tissues above the soil surface were removed using a small pruning shears. The initial soil moisture content is also among the factors affecting soil hydrological responses (Chow et al., 1988), which was about 29 volumetric $\%$ and relatively the same in all 18 plots. A view of the plots both before and after soil preparation is shown in Fig. 2 .

\subsection{Rainfall simulation}

According to Kojour synoptic rain gauge data and IDF curves, which is the nearest station to the study slope, three rainfall intensities of 40,60 and $80 \mathrm{~mm} \mathrm{~h}^{-1}$ were selected with a constant duration of $15 \mathrm{~min}$ after time to runoff. These ranges of rainfall intensities are among the most erosive rainfalls in the study area because they have erosive intensities and as well as enough durations and return periods (20 years). According to the IDF curves, all three intensities of 40,60 and $80 \mathrm{~mm} \mathrm{~h}^{-1}$ had a duration equal to or longer than $15 \mathrm{~min}$ in a return period of 20 years. A portable rainfall simulator was then used to simulate rainfall events using one or two nozzles of BEX: 3/8 S24W for various rainfall intensities with a constant height of $3 \mathrm{~m}$ above the soil surface. The median diameter and velocity of simulated raindrops were determined processing the images of a high-speed camera (Canon EOS 550D). The median diameters of raindrops were $1.11,1.05$ and $1.03 \mathrm{~mm}$, and the mean velocities of raindrops were $4.38,4.08$ and $4.03 \mathrm{~m} \mathrm{~s}^{-1}$ for three studied rainfall intensities respectively. The kinetic energy of simulated rainfalls was then calculated using the main kinetic energy formula $\left(E=1 / 2 \mathrm{mv}^{2}\right)$ and the average volume and number of raindrops per $\mathrm{mm}$ depth of rainfall. The kinetic energy of simulated rainfalls was $9.59,8.32$ and $8.12 \mathrm{~J} \mathrm{~m}^{-2} \mathrm{~mm}^{-1}$ for three studied rainfall intensities respectively. This rainfall simulator uses similar rainfall characteristics to other ones such as in Cerdà (1998a), Keesstra et al. (2014), Lassu et al. (2015) and Cerdà et al. (2016).

\subsection{Measuring runoff, sediment concentration and soil loss}

During each experiment, runoff was collected in the outlet of plots and sampled in five $3 \mathrm{~min}$ intervals after runoff commencement time. The time of fifth sample was exactly coincident with the time the rain had stopped; then all the remained runoff was collected as the final sixth sample. The samples were transferred to the laboratory, and sediment concentration was measured using the decantation procedure and oven-dried at $105^{\circ} \mathrm{C}$ for $24 \mathrm{~h}$ (Gholami et al., 2013). 


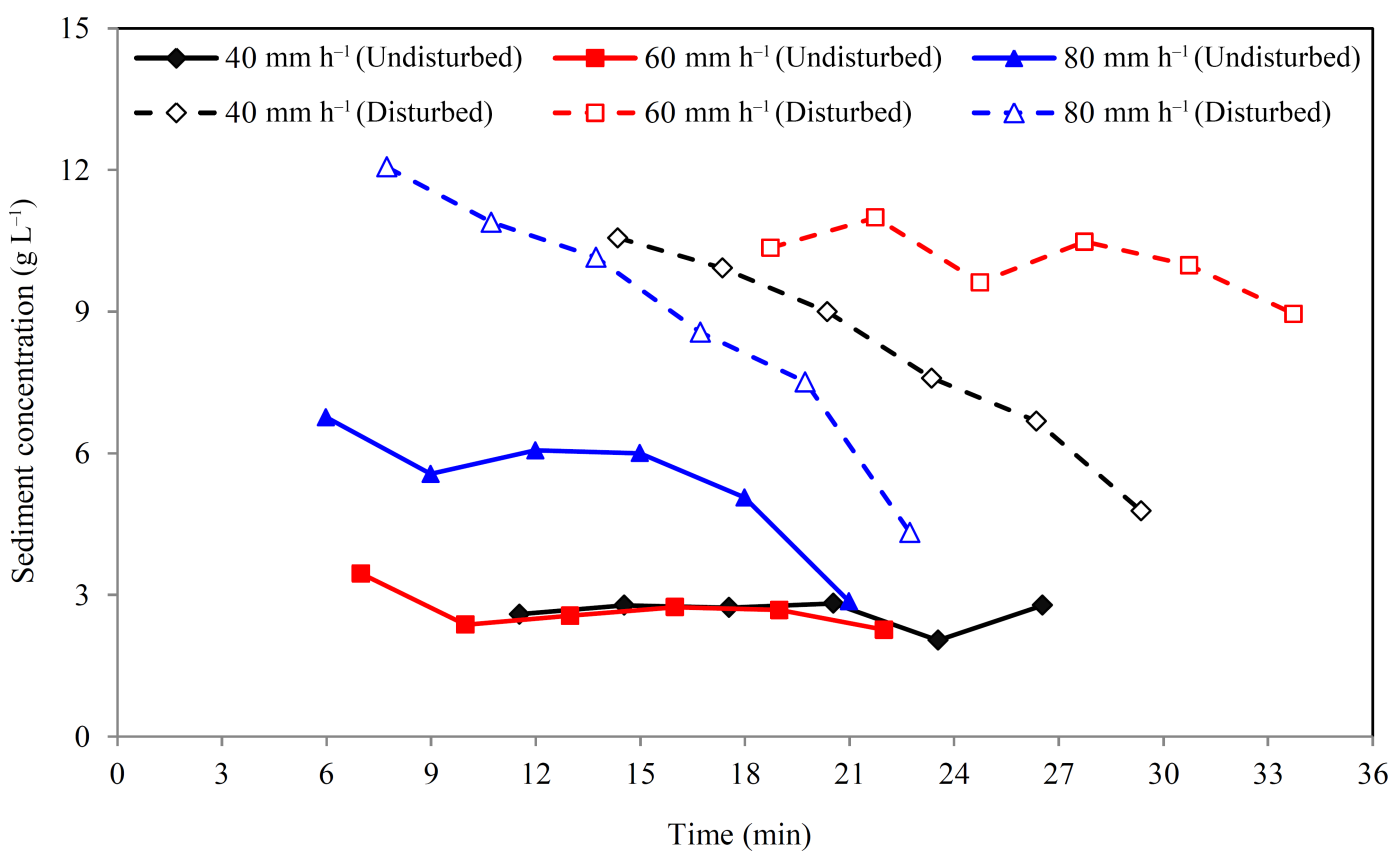

Figure 3. Mean temporal variation of sediment concentrations in three replications before and after soil preparation treatments.

\subsection{Statistical analysis}

The effects of soil preparation practice on the variables of time to runoff, runoff volume and coefficient, sediment concentration, and soil loss were analyzed. The statistical tests were performed under experimental design of spilt plots and factorial experiments with two soil conditions (before and after soil preparation) and three rainfall intensities. The normality test was done for all variables of runoff, sediment concentration and soil loss. Based on the results of normality test, the runoff volume and soil loss datasets were transformed to logarithmic form to achieve normality distribution because parametric tests on normal data seem to be more powerful to detect the differences than the nonparametric tests on non-normal data (Townend, 2002).

The ANOVA tests considering the split plot design (Bihamta and Zare Chahouki, 2011) were finally used to evaluate the statistical differences between studied variables before and after soil preparation.

\section{Results and discussion}

The results of average runoff variables, sediment concentration and soil loss for three replicates of both before and after soil preparation in three studied rainfall intensities are shown in Tables 1 to 3 respectively.

The statistical analyses of the effects of rainfall intensity and soil preparation on sediment concentration and soil loss are shown in Table 4.
Mean temporal variation of sediment concentrations in three replications of before and after soil preparation is shown in Fig. 3, and increasing ratios (\%) of runoff variables, sediment concentration and soil loss after preparing soil are shown in Fig. 4.

According to Table 1, weighted mean runoff coefficients of the average values of various time intervals were varied from 6.82 to 25.70 before soil preparation condition and from 25.08 to 57.17 after soil preparation condition. The results revealed that soil preparation leads to a significant $(p \leq 0.01)$ increase in runoff coefficient (Table 4).

According to Table 2, weighted mean sediment concentrations of the average values of various time intervals were varied from 2.7 to 7.57 and from 10.38 to 12.41 before and after soil preparation respectively. According to Tables 2 and 4 , the sediment concentration was significantly $(p \leq 0.01)$ increased after soil preparation for laboratory erosion plots. One of the reasons for more sediment concentration before soil preparation is the longer time to runoff, which leads to more splash and particle separation before the flow of surface runoff. Consequently, in the first sampling after runoff commencement time, the available source of soil particles to be transport is more and leads to an increase in sediment concentration. But a few minutes after runoff commencement time, the available sediment source and, consequently, the sediment concentration decrease. The effects of soil preparation practice for laboratory erosion plots on runoff or soil loss were in agreement with previous studies which revealed the same effects of soil preparation for agriculture and gardening purposes (Harold et al., 1945; Choudhary et al., 1997; Layon et al., 1999; Erkossa et al., 2005; Gomez and Nearing, 2005; 


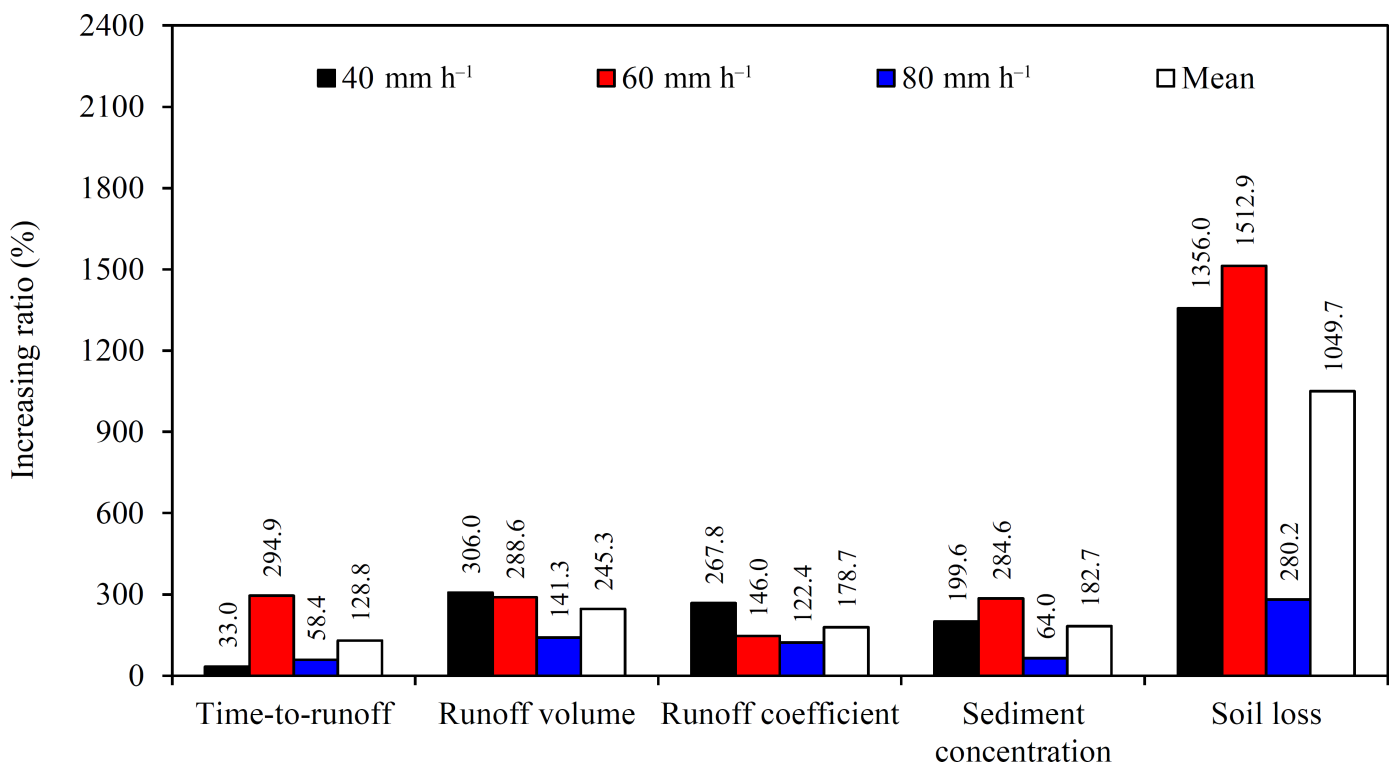

Figure 4. Increasing ratios of runoff variables, sediment concentration and soil loss after preparing soil.

Table 1. The average time to runoff and runoff volume for three replicates of both before and after soil preparation treatments in three studied rainfall intensities.

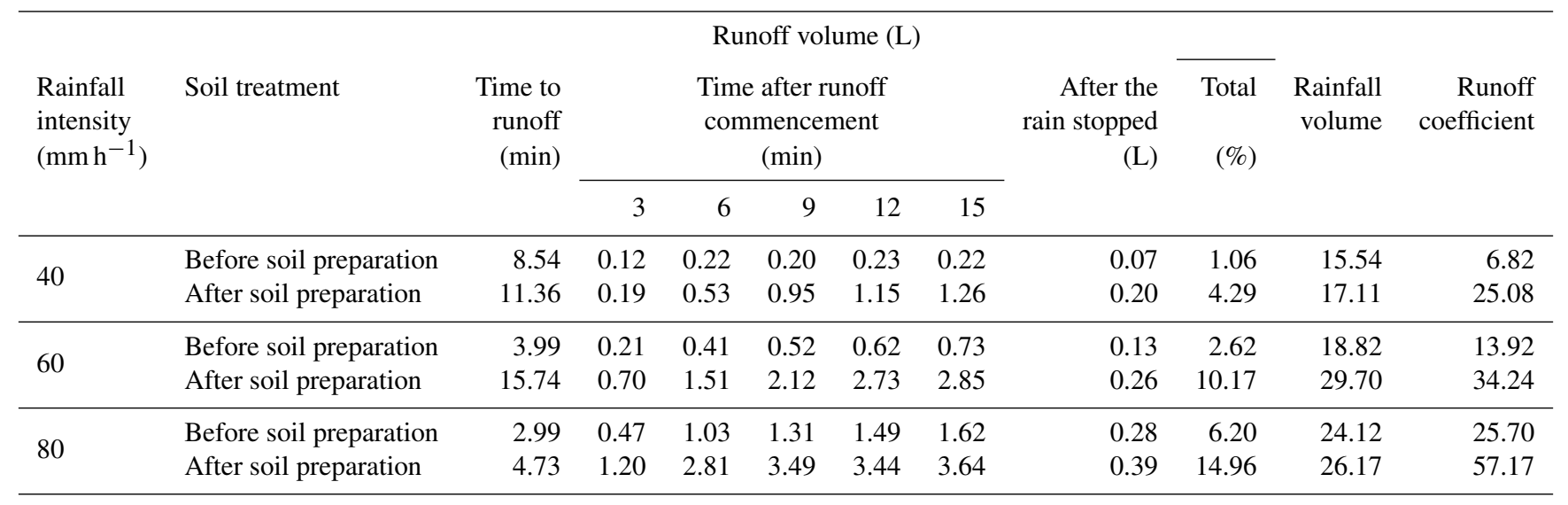

Nanko et al., 2015; Navarro-Hevia et al., 2016). The results were in agreement with Cao et al. (2015), who studied and modeled the interrill erosion on unpaved roads, and Villarreal et al. (2016), who studied the effects of vehicle-based soil disturbance and compaction on soil erosion potential. Soil surface disturbance and compaction because of grazing can increase soil erosion (Palacio et al., 2014). In other words, soil preparation - for any purposes especially for laboratory erosion plots - could decrease soil resistance against raindrops because of aggregate breakdown, which leads to more detachment, less infiltration, more runoff and more sediment concentration. Concentrations of runoff sediment after soil preparation confirmed that erosion depended directly on the sediment available on the soil surface that was in agreement with Ceballos et al. (2002). The presence of pebbles and gravels on soil surface as well as inside soil profile has been considered as an affective factor against the kinetic energy of raindrops (Jomaa et al., 2012). The presence of stones at the soil surface does not always decrease soil erosion; on the contrary, if stones are embedded in crusted surfaces, they can increase runoff and thus soil erosion. The roots and other plant residues can also play a significant role in physically decreasing the kinetic energy of raindrops and improving aggregate stability (Monroe and Kladivko, 1987; Ghidey and Alberts, 1997; Martens, 2002). Removing all pebbles, gravels and plant residues could also been considered as another significant reason which leads to more sediment concentration in prepared soil for laboratory studies. All these results mean that more splash in prepared soil is one the main consequences of increasing sediment concentration.

All the steps of soil preparation (i.e., sampling, transporting, spreading to be air-dried, passing through $8 \mathrm{~mm}$ sieve, 
Table 2. The average sediment concentration for three replicates of both before and after soil preparation treatments in three studied rainfall intensities.

\begin{tabular}{|c|c|c|c|c|c|c|c|c|}
\hline \multirow{3}{*}{$\begin{array}{l}\text { Rainfall } \\
\text { intensity } \\
\left(\mathrm{mm} \mathrm{h}^{-1}\right)\end{array}$} & \multirow{3}{*}{ Soil treatment } & \multicolumn{7}{|c|}{ Sediment concentration $\left(\mathrm{g} \mathrm{L}^{-1}\right)$} \\
\hline & & \multicolumn{5}{|c|}{$\begin{array}{c}\text { Time after runoff } \\
\text { commencement } \\
\text { (min) }\end{array}$} & \multirow[t]{2}{*}{$\begin{array}{l}\text { After the } \\
\text { rain stopped }\end{array}$} & \multirow[t]{2}{*}{$\begin{array}{r}\text { Weighted } \\
\text { mean }\end{array}$} \\
\hline & & 3 & 6 & 9 & 12 & 15 & & \\
\hline \multirow{2}{*}{40} & Before soil preparation & 2.59 & 2.78 & 2.73 & 2.82 & 2.04 & 2.78 & 3.49 \\
\hline & After soil preparation & 10.56 & 9.92 & 9.00 & 7.59 & 6.68 & 4.78 & 10.44 \\
\hline \multirow{2}{*}{60} & Before soil preparation & 3.45 & 2.37 & 2.56 & 2.74 & 2.68 & 2.26 & 2.70 \\
\hline & After soil preparation & 10.35 & 10.99 & 9.62 & 10.48 & 9.98 & 8.95 & 10.38 \\
\hline \multirow{2}{*}{80} & Before soil preparation & 6.76 & 5.56 & 6.06 & 6.00 & 5.06 & 2.86 & 7.57 \\
\hline & After soil preparation & 12.06 & 10.89 & 10.15 & 8.56 & 7.51 & 4.32 & 12.41 \\
\hline
\end{tabular}

Table 3. The average soil loss for three replicates of both before and after soil preparation treatments in three studied rainfall intensities.

\begin{tabular}{|c|c|c|c|c|c|c|c|c|}
\hline \multirow{3}{*}{ Rainfall intensity $\left(\mathrm{mm} \mathrm{h}^{-1}\right)$} & \multirow{3}{*}{ Soil treatment } & \multicolumn{7}{|c|}{ Soil loss (g) } \\
\hline & & \multicolumn{5}{|c|}{$\begin{array}{c}\text { Time after runoff } \\
\text { commencement (min) }\end{array}$} & \multirow[t]{2}{*}{$\begin{array}{l}\text { After the } \\
\text { rain stopped }\end{array}$} & \multirow[t]{2}{*}{$\begin{array}{r}\text { Total soil } \\
\text { loss }\end{array}$} \\
\hline & & 3 & 6 & 9 & 12 & 15 & & \\
\hline \multirow{2}{*}{40} & Before soil preparation & 0.28 & 0.50 & 0.50 & 0.61 & 0.39 & 0.12 & 3.19 \\
\hline & After soil preparation & 2.12 & 5.36 & 8.69 & 8.97 & 8.72 & 0.96 & 46.42 \\
\hline \multirow{2}{*}{60} & Before soil preparation & 0.79 & 0.79 & 1.42 & 1.87 & 2.00 & 0.27 & 7.15 \\
\hline & After soil preparation & 8.12 & 18.39 & 22.84 & 33.30 & 30.10 & 2.50 & 115.25 \\
\hline \multirow{2}{*}{80} & Before soil preparation & 4.07 & 8.18 & 12.32 & 12.20 & 11.62 & 1.05 & 49.45 \\
\hline & After soil preparation & 20.04 & 41.99 & 47.06 & 39.76 & 36.96 & 2.20 & 188.02 \\
\hline
\end{tabular}

packing into the plots and compacting again) are the reasons for damage to soil structure and aggregate breakdown even without removing any parts of the soil materials.

Using a sieve with larger mesh number $(8 \mathrm{~mm})$ may decrease the negative effects of soil preparation (Khaleidi Darvishan et al., 2014), but a significant part of effects that are connected to sampling, transporting and especially compacting the soil still remain.

Longer time to runoff before soil preparation revealed that preparing soil, even with compacting again, can cause a temporary increase in infiltration, which itself leads to longer time to runoff (Table 1). But the main note is that the increasing infiltration is a temporary effect of preparing soil, and after a few minutes more detachment can decrease the infiltration rate, leading to more runoff volume in the first $3 \mathrm{~min}$ sampling interval after runoff commencement time (Fig. 3). The results showed that in all three rainfall intensities, sediment concentration in both before and after soil preparation treatments reached the peak in the first sample of runoff and then gradually decreased. This result was in agreement with a lot of other laboratory soil erosion research (Assouline and Ben-Hur, 2006).

The significant effect of soil preparation practice on soil loss may be due to eliminated surface gravel during sieving of the soil. This may be because of the ability of gravel surface to reduce total amount of available sediment (Tailong et al., 2010) and also to decrease power erosivity of surface flow (Rieke-Zapp et al., 2007; Tailong et al., 2010). Rock fragments, roots and plants debris on the soil surface and within the soil profile in soil surface before any preparation practice could protect the aggregate against raindrops or runoff flow. In this regard, Li et al. (1991), Ghidey and Alberts (1997) and Mamo and Bubenzer (2001a, b) showed that root system helps the soil resistance and thus reduces the amount of soil loss.

According to Table 4, the increasing effects of rainfall intensity on runoff coefficient, sediment concentration and soil loss were significant. The significant effects of rainfall intensity on various runoff, sediment and soil loss variables have been emphasized by Romkens et al. (2001), Chaplot and Le 
Table 4. Statistical analysis of the effects of soil preparation treatment and rainfall intensity on sediment concentration and soil loss.

\begin{tabular}{|c|c|c|c|c|c|c|}
\hline Source & Dependent variable & $\begin{array}{l}\text { Sum of } \\
\text { squares }\end{array}$ & $\mathrm{d} f$ & $\begin{array}{r}\text { Mean } \\
\text { squares }\end{array}$ & $f$ & $p$ value \\
\hline \multirow{3}{*}{ Treatment } & Runoff coefficient (\%) & 2425.56 & \multirow{3}{*}{1} & 2425.56 & 15.963 & $0.005^{\mathrm{b}}$ \\
\hline & Sediment concentration $\left(\mathrm{g} \mathrm{L}^{-1}\right)$ & 189.67 & & 189.67 & 26.794 & $0.003^{\mathrm{b}}$ \\
\hline & Log_Soil_Loss (g) & 4.56 & & 4.56 & 49.192 & $0.000^{\mathrm{b}}$ \\
\hline Treatment & Runoff coefficient (\%) & 607.61 & \multirow{3}{*}{4} & 151.90 & 0940 & 0.488 \\
\hline$x$ & Sediment concentration $\left(\mathrm{g} \mathrm{L}^{-1}\right)$ & 28.33 & & 7.08 & 1.579 & 0.269 \\
\hline Repetition & Log_Soil_Loss (g) & 0.37 & & 0.09 & 0.861 & 0.526 \\
\hline \multirow{3}{*}{ Rainfall intensity } & Runoff coefficient $(\%)$ & 2043.90 & \multirow{3}{*}{2} & 1021.95 & 6.322 & $0.023^{\mathrm{a}}$ \\
\hline & Sediment concentration $\left(\mathrm{g} \mathrm{L}^{-1}\right)$ & 42.52 & & 21.26 & 4.742 & $0.044^{\mathrm{a}}$ \\
\hline & Log_Soil_Loss (g) & 2.54 & & 1.27 & 11.820 & $0.004^{\mathrm{b}}$ \\
\hline Rainfall intensity & Runoff coefficient (\%) & 15.41 & \multirow{3}{*}{2} & 77.71 & 0.481 & 0.635 \\
\hline$x$ & Sediment concentration $\left(\mathrm{g} \mathrm{L}^{-1}\right)$ & 6.54 & & 3.27 & 0.729 & 0.512 \\
\hline Treatment & Log_Soil_Loss (g) & 0.30 & & 0.15 & 1.410 & 0.299 \\
\hline \multirow{3}{*}{ Error } & Runoff coefficient $(\%)$ & 1293.20 & \multirow{3}{*}{8} & 161.65 & & \\
\hline & Sediment concentration $\left(\mathrm{g} \mathrm{L}^{-1}\right)$ & 35.87 & & 4.48 & & \\
\hline & Log_Soil_Loss (g) & 0.86 & & 0.11 & & \\
\hline
\end{tabular}

${ }^{\mathrm{a}}$ and ${ }^{\mathrm{b}}$ are the significant levels of 95 and $99 \%$, respectively.

Bissonnais (2003), Assouline and Ben-Hur (2006), Ahmed et al. (2012) and Defersha and Melesse (2012) too.

The results of statistical analysis (Table 4) showed that the interaction between rainfall intensity and soil preparation treatment on sediment concentration was not significant, which may be due to the limited studied levels of rainfall intensity $\left(40,60\right.$ and $\left.80 \mathrm{~mm} \mathrm{~h}^{-1}\right)$. All rainfall intensities may also high enough to seal the soil surface. In other words, for lower rainfall intensities (for example $20 \mathrm{~mm} \mathrm{~h}^{-1}$ ), probably one could find an interaction between rainfall intensity and soil preparation treatment.

\section{Conclusions}

It can be generally concluded that the average and peak values and variation gradient of runoff and sediment concentration increased due to soil preparation practice. The increasing rates of runoff coefficient, sediment concentration and soil loss due to the study soil preparation method for laboratory soil erosion plots were 179,183 and $1050 \%(2.79,2.83$ and 11.50 times), respectively. The observed differences indicated that the use of laboratory plots is not appropriate to predict soil erosion of natural conditions, while their results can be used to compare soil erosion rates in various treatments and conditions. It is highly recommended to leave the prepared soil inside the plots at least for a few weeks before rainfall simulation instead of using a roller to increase the bulk density and improve structural condition of the soil. It may decrease the negative effects of soil preparation process caused by rolling the soil surface. The soil moisture content during the process especially after packing the prepared soil inside the plots is also very important and can lead to an increase in the bulk density in a shorter time. The results of this research are valid only for a natural cover (rangeland) on specific soil and could not be extended to any other land use and soil conditions. In addition, the slope length was not long enough to produce rills; therefore, the results are valid only when splash and sheet erosion are dominant erosion processes.

\section{Data availability}

All gained data can be assessed by asking for them the author via an e-mail (a.khaledi@modares.ac.ir).

Author contributions. Abdulvahed Khaledi Darvishan designed research methods. Abdulvahed Khaledi Darvishan and Vafa Homayounfar designed and calibrated the rainfall simulator and collected all data in the field. Abdulvahed Khaledi Darvishan and Seyed Hamidreza Sadeghi processed them. Abdulva- 
hed Khaledi Darvishan and Vafa Homayounfar prepared the manuscript.

Acknowledgements. This project was funded by the Faculty of Natural Resources at Tarbiat Modares University of Iran. Authors also thank the laboratory assistants and other postgraduate students for their help in running experiments and collecting data.

Edited by: A. Cerdà

Reviewed by: three anonymous referees

\section{References}

Agassi, M. and Bradford, J. M.: Methodologies for interrill soil erosion studies, Soil Till. Res., 49, 277-287, 1999.

Ahmed, S. I., Rudra, R. P., Gharabaghi, B., Mackenzie, K., and Dickinson, W. T.: Within-storm rainfall distribution effect on soil erosion rate, ISRN Soil Sci., Article ID: 310927, 7 pp., 2012.

Assoulin, S. and Ben-Hu, M.: Effects of rainfall intensity and slope gradient on the dynamics of interrill erosion during soil surface sealing, Catena, 66, 211-220, 2006.

Bihamta, M. R. and Zare Chahouki, M. A.: Statistics principles in natural resources, 2nd Edn., Tehran University Press, Iran, 300 pp., 2011 (in Persian).

Biswas, H., Raizada, A., Mandal, D., Kumar, S., Srinivas, S., and Mishra, P. K.: Identification of areas vulnerable to soil erosion risk in India using GIS methods, Solid Earth, 6, 1247-1257, doi:10.5194/se-6-1247-2015, 2015.

Bochet, E.: The fate of seeds in the soil: a review of the influence of overland flow on seed removal and its consequences for the vegetation of arid and semiarid patchy ecosystems, SOIL, 1, 131-146, doi:10.5194/soil-1-131-2015, 2015.

Borrelli, P., Märker, M., and Schütt, B.: Modelling Post-TreeHarvesting soil erosion and sediment deposition potential in the turano river basin (Italian central apennine), Land Degrad. Dev., 26, 356-366, 2015.

Brevik, E. C., Cerdà, A., Mataix-Solera, J., Pereg, L., Quinton, J. N., Six, J., and Van Oost, K.: The interdisciplinary nature of SOIL, SOIL, 1, 117-129, doi:10.5194/soil-1-117-2015, 2015.

Cao, L., Zhang, K., Dai, H., and Liang, Y.: Modeling Interrill Erosion on Unpaved Roads in the Loess Plateau of China, Land Degrad. Dev., 26, 825-832, 2015.

Ceballos, A. Cerdà, A., and Schnabel, S.: Runoff production and erosion processes on a Dehesa in Western Spain, Geogr. Rev., 92, 333-353, 2002.

Cerdà, A.: Effect of climate on surface flow along a climatological gradient in Israel, A field rainfall simulation approach, J. Arid Environ., 38, 145-159, 1998a.

Cerdà, A.: The influence of aspect and vegetation on seasonal changes in erosion under rainfall simulation on a clay soil in Spain, Can. J. Soil Sci., 78, 321-330, 1998b.

Cerdà, A.: Seasonal and spatial variations in infiltration rates in badland surfaces under Mediterranean climatic conditions, Water Resour. Res., 35, 319-328, 1999.

Cerdà, A.: The effect of season and parent material on water erosion on highly eroded soils in eastern Spain, J. Arid Environ., 52, 319337, 2002.
Cerdà, A., Ibáñez, S., and Calvo, A.: Design and operation of a small and portable rainfall simulator for rugged terrain, Soil Technol., 11, 161-168, 1997.

Cerdà, A., Flanagan, D. C., le Bissonnais, Y., and Boardman, J.: Soil erosion and agriculture, Soil Till. Res., 106, 107-108, 2009a.

Cerdà, A., Giménez-Morera, A., and Bodí, M.B.: Soil and water losses from new citrus orchards growing on sloped soils in the western Mediterranean basin, Earth Surf. Proc. Land., 34, 18221830, 2009b.

Cerdà, A., Brazier, R., Nearing, M., and de Vente, J.: Scales and erosion, Catena, 102, 1-2, 2013.

Cerdà, A., González-Pelayo, O., Giménez-Morera, A., Jordán, A., Pereira, P., Novara, A., Brevik, E. C., Prosdocimi, M., Mahmoodabadi, M., Keesstra, S., García Orenes, F., and Ritsema, C.: The Use of barley straw residues to avoid high erosion and runoff rates on persimmon plantations in Eastern Spain under low frequency - high magnitude simulated rainfall events, Soil Res., 54, 154-165, doi:10.1071/SR15092, 2016.

Chaplot, V. A. M. and Le Bissonnais, Y.: Runoff features for interrill erosion at different rainfall intensities, slope lengths, and gradients in an agricultural loessial hillslope, Soil Sci. Soc. Am. J., 67, 844-851, 2003.

Choudhary, M. A., Lal, A. R., and Dick, W. A.: Long-term tillage effects on runoff and soil erosion under simulated rainfall for a Central Ohio soil, Soil Till. Res., 42, 175-184, 1997.

Chow, V. T., Maidment, D. R., and Mays, L. W., Appl. Hydrol., McGraw-Hill, India, 1988.

Davudirad, A. A., Sadeghi, S. H., and Sadoddin, A.: The Impact of Development Plans on Hydrological Changes in the Shazand Watershed, Iran, Land Degrad. Dev., 27, 1236-1244, 2016.

Defersha, M. B. and Mellese, A. M.: Effect of rainfall intensity, slope and antecedent moisture content on sediment concentration and sediment enrichment ratio, Catena 90, 47-52, 2012.

Defersha, M. B., Quraishi, S., and Melesse, A.: The effect of slope steepness and antecedent moisture content on interrill erosion, runoff and sediment size distribution in the highlands of Ethiopia, Hydrol. Earth Syst. Sci., 15, 2367-2375, doi:10.5194/hess-152367-2011, 2011.

Ekwue, E. I: The effects of soil organic matter content, rainfall duration and aggregate size on soil detachment, Soil Tech., 4, 197207, 1991.

Ekwue, E. I. and Harrilal, A.: Effect of soil type, peat, slope, compaction effort and their interactions on infiltration, runoff and raindrop erosion of some trinidadian soils, Biosyst. Eng., 105, 112-118, 2010.

Erkossa, T., Stahr, K., and Gaiser, T.: Effect of different methods of land preparation on runoff, soil and nutrient losses from a Vertisol in the Ethiopian highlands, Soil Use Manage., 21, 253-259, 2005.

Fox, D. M. and Bryan, R. B.: The relationship of soil loss by interrill erosion to slope gradient, Catena, 38, 211-222, 1999.

Ghidey, F. and Alberts, E. E.: Plant root effects on soil erodibility, splash detachment, soil strength, and aggregate stability, T. Am. Soci. Agricul. Eng., 40, 129-135, 1997.

Gholami, L., Sadeghi, S. H. R., and Homaee, M.: Straw mulching effect on splash erosion, runoff and sediment yield from eroded plots, Soil Sci. Soci. Am. J., 77, 268-278, 2013.

Gholami, L., Banasik, K., Sadeghi, S. H. R., Khaledi Darvishan, A., and Hejduk, L.: Effectiveness of Straw Mulch on Infiltration, 
Splash Erosion, Runoff and Sediment in Laboratory Conditions, J. Water Land Develop., 22, 51-60, 2014.

Gomez, J. A. and Nearing, M. A.: Runoff and sediment losses from rough and smooth soil surfaces in a laboratory experiment, Catena, 59, 253-266, 2005.

Harold, L. B., Mccall, A. G., and Bell, F. G.: Investigations in erosion control and reclamation of eroded land at the northwest appalachian conservation experiment station, Zanesville, Ohio, United States Department of Agriculture, Technical Bulettin, 888, 95 pp., 1945.

Hawke, R. M., Price, A. G., and Bryan, R. B.: The effect of initial soil water content and rainfall intensity on near-surface soil hydrologic conductivity: A laboratory investigation, Catena, 65, 237-246, 2006.

Iserloh, T., Ries, J. B., Cerdà, A., Echeverría, M. T., Fister, W., Geißler, C., Kuhn, N. J., León, F. J., Peters, P., Schindewolf, M., Schmidt, J., Scholten, T., and Seeger, M.: Comparative measurements with seven rainfall simulators on uniform bare fallow land, Z. Geomorphol., 57, 193-201, 2012.

Iserloh, T., Ries, J. B., Arnaez, J., Boix Fayos, C., Butzen, V., Cerdà, A., Echeverría, M. T., Fernández-Gálvez, J., Fister, W., Geißler, C., Gómez, J. A., Gómez-Macpherson, H., Kuhn, N. J., Lázaro, R., León, F. J., Martínez-Mena, M., Martínez-Murillo, J. F., Marzen, M., Mingorance, M. D., Ortigosa, L., Peters, P., Regüés, D., Ruiz-Sinoga, J. D., Scholten, T., Seeger, M., Solé-Benet, A., Wengel, R., and Wirtz, S.: European small portable rainfall simulators: a comparison of rainfall characteristics, Catena, 110, 100$112,2013$.

Jomaa, S., Barry, D. A., Brovelli, A., Heng, B. C. P., Sander, G. C., Parlange, J. Y., and Rose, C. W.: Rain splash soil erosion estimation in the presence of rock fragments, Catena, 92, 38-48, 2012.

Keesstra, S. D., Maroulis, J., Argaman, E., Voogt, A., and Wittenberg, L.: Effects of controlled fire on hydrology and erosion under simulated rainfall, Cuadernos de Investigación Geográfica, 40, 269-293, 2014.

Keesstra, S. D., Bouma, J., Wallinga, J., Tittonell, P., Smith, P., Cerdà, A., Montanarella, L., Quinton, J. N., Pachepsky, Y., van der Putten, W. H., Bardgett, R. D., Moolenaar, S., Mol, G., Jansen, B., and Fresco, L. O.: The significance of soils and soil science towards realization of the United Nations Sustainable Development Goals, SOIL, 2, 111-128, doi:10.5194/soil-2-1112016, 2016.

Khaledi Darvishan, A., Sadeghi, S. H. R., Homaee, M., and Arabkhedri, M.: Potential use of synthetic color-contrast aggregates and a digital image processing technique in soil splash measurements, in: Erosion and Sediment Yields in the Changing Environment, IAHS Publication 356, Wallingford, Oxfordshire, UK, 364-368, 2012.

Khaledi Darvishan, A. V., Sadeghi, S. H. R. Homaee, M., and Arabkhedri, M.: Measuring sheet erosion using synthetic colorcontrast aggregates, Hydrol. Process. 28, 4463-4471, 2014.

Kirkby, M.: Modeling the interactions between soil surface properties and water, Elsevier Catena, 46, 89-102, 2001.

Kukal, S. S. and Sarkar, M.: Splash erosion and infiltration in relation to mulching and polyviny alcohol application in semi-arid tropics, Arch. Agronom. Soil Sci., 56, 697-705, 2010.
Kukal, S. S. and Sarkar, M.: Laboratory simulation studies on splash erosion and crusting in relation to surface roughness and raindrop size, J. Indian Soc. Soil Sci., 59, 87-93, 2011.

Lassu, T., Seeger, M., Peters, P., and Keesstra, S. D.: The Wageningen Rainfall Simulator: Set-up and Calibration of an Indoor Nozzle-Type Rainfall Simulator for Soil Erosion Studies, Land Degrad. Dev., 26, 604-612, 2015.

Layon, T. L., Buckman, H. O., and Brady N. C.: The nature and properties of soil, 12th Edn., Mac Millan Co., New York, 1952.

Le Bissonnais, Y., Montier, C., Jamagne, M., Daroussin, J., and King, D.: Mapping erosion risk for cultivated soil in France, Catena, 46, 207-220, 2002.

León, J., Bodí, M. B., Cerdà, A., and Badía, D.: The contrasted response of ash to wetting: The effects of ash type, thickness and rainfall events, Geoderma, 209/210, 143-152, 2013.

Li, Y., Zhu, X., and Tian, J.: Effectiveness of plant roots to increasethe anti-scourability of soil on the Loess Plateau, Chinese Sci. Bull., 36, 2077-2082, 1991.

Licznar, P. and Nearing, M. A.: Artificial neural networks of soil erosion and runoff prediction at the plot scale, Catena, 51, 89114, 2003.

Lieskovský, J. and Kenderessy, P.: Modelling the effect of vegetation cover and different tillage practices on soil erosion in vineyards: a case study en Vráble (Slovakia) using WATEM/SEDEM, Land Degrad. Dev., 25, 288-296, 2014.

Ligonja, P. J. and Shrestha, R. P.: Soil erosion assessment in kondoa eroded area in Tanzania using universal soil loss equation, geographic information systems and socioeconomic approach, Land Degrad. Dev., 26, 367-379, 2015

Luk, S. H.: Effect of antecedent soil moisture content on rainwash erosion, Catena, 12, 129-139, 1985.

Mamo, M. and Bubenzer, G. D.: Detachment rate, soil erodibility and soil strength as influenced by living plant roots: Part I, Laboratory study, Am. Soci. Agricul. Eng., 44, 1167-1174, 2001a.

Mamo, M. and Bubenzer, G. D.: Detachment rate, soil erodibility and soil strength as influenced by living plant roots: Part II, Field study, Am. Soc. Agr. Eng., 44, 1175-1181, $2001 b$.

Martens, D. A.: Relationship between plant phenolic acids released during soil mineralization and aggregate stabilization, Soil Sci. Soc. Am. J., 66, 1857-1867, 2002.

Martín-Moreno, C., Martín Duque, J. F., Nicolau Ibarra, J. M., Hernando Rodríguez, N., Sanz Santos, M. A., and Sánchez Castillo, L.: Effects of Topography and Surface Soil Cover on Erosion for Mining Reclamation: The Experimental Spoil Heap at El Machorro Mine (Central Spain), Land Degrad. Dev., 27, 145-159, 2016.

Martínez-Murillo, J. F., Nadal-Romero, E., Regües, D., Cerdà, A., and Poesen, J.: Soil erosion and hydrology of the western Mediterranean throughout rainfall simulation experiments: A review, Catena, 106, 101-112, 2013.

Monroe, C. D. and Kladivko, E. J.: Aggregate stability of a silt loam soil as affected by roots of corn, soybeans, and wheat, Commun. Soil Sci. Plant Anal., 18, 1077-1087, 1987.

Nanko, K., Giambelluca, T. W., Sutherland, R. A., Mudd, R. G., Nullet, M. A., and Ziegler, A. D.: Erosion potential under miconia calvescens stands on the island of Hawai' $i$, Land Degrad. Dev., 26, 218-226, 2015. 
Navarro-Hevia, J., Lima-Farias, T. R., de Araújo, J. C., OsorioPeláez, C., and Pando, V.: Soil Erosion in Steep Road Cut Slopes in Palencia (Spain), Land Degrad. Dev., 27, 190-199, 2016.

Novara, A., Gristina, L., Saladino, S. S., Santoro, A., and Cerdà, A.: Soil erosion assessment on tillage and alternative soil managements in a Sicilian vineyard, Soil Till. Res., 117, 140-147, 2011.

Novara, A., Keesstra, S., Cerdà, A., Pereira, P., and Gristina, L.: Understanding the role of soil erosion on $\mathrm{CO}_{2}-\mathrm{C}$ loss using ${ }^{13} \mathrm{C}$ isotopic signatures in abandoned Mediterranean agricultural land, Sci. Total Environ., 550, 330-336, 2016.

Ochoa, P. A., Fries, A., Mejía, D., Burneo, J. I., Ruíz-Sinoga, J. D., and Cerdà, A.: Effects of climate, land cover and topography on soil erosion risk in a semiarid basin of the Andes, Catena, 140, 31-42, 2016.

Ochoa-Cueva, P., Fries, A., Montesinos, P., Rodríguez-Díaz, J. A., and Boll, J.: Spatial Estimation of Soil Erosion Risk by Landcover Change in the Andes of Southern Ecuador, Land Degrad. Dev., 26, 565-573, 2015.

Palacio, R. G., Bisigato, A. J., and Bouza, B. J.: Soil erosion in three grazed plant communities in northeastern Patagonia, Land Degrad. Dev., 25, 594-603, doi:10.1002/ldr.2289, 2014.

Pereira, P., Gimeìnez-Morera, A., Novara, A., Keesstra, S., Jordán, A., Masto, R. E., Brevik, E., Azorin-Molina, C., and Cerdà, A.: The impact of road and railway embankments on runoff and soil erosion in eastern Spain, Hydrol. Earth Syst. Sci. Discuss., 12, 12947-12985, doi:10.5194/hessd-12-12947-2015, 2015.

Prosdocimi, M., Cerdà, A., and Tarolli, P.: Soil water erosion on Mediterranean vineyards: A review, Catena, 141, 1-21, 2016.

Ramos, M. C., Nacci, S., and Pla, I.: Soil sealing and its influence on erosion rates for some soils in the Mediterranean area, Soil Sci., 165, 398-403, 2000.

Rieke-Zapp, D., Poesen, J., and Nearing, M. A.: Effects of rock fragments incorporated in the soil matrix on concentrated flow hydraulics and erosion, Earth Surf. Proc. Land., 32, 1063-1076, 2007.

Rodrigo Comino, J., Brings, C., Lassu, T., Iserloh, T., Senciales, J. M., Martínez Murillo, J. F., Ruiz Sinoga, J. D., Seeger, M., and Ries, J. B.: Rainfall and human activity impacts on soil losses and rill erosion in vineyards (Ruwer Valley, Germany), Solid Earth, 6, 823-837, doi:10.5194/se-6-823-2015, 2015.

Rodrigo Comino, J., Iserloh, T., Morvan, X., Malam Issa, O., Naisse, C., Keesstra, S. D., Cerdà, A., Prosdocimi, M., Arnáez, J., Lasanta, T., Ramos, M. C., Marqués, M. J., Ruiz Colmenero, M., Bienes, R., Ruiz Sinoga, J. D., Seeger, M., and Ries, J. B.: Soil Erosion Processes in European Vineyards: A Qualitative Comparison of Rainfall Simulation Measurements in Germany, Spain and France, Hydrology, 3, 1-19,, 2016a.
Rodrigo Comino, J., Iserloh, T., Lassu, T., Cerdà, A., Keesstra, S. D., Prosdocimi, M., Brings, C., Marzen, M., Ramos, M. C., Senciales, J. M., Ruiz Sinoga, J. D., Seeger, M., and Ries, J. B. Quantitative comparison of initial soil erosion processes and runoff generation in Spanish and German vineyards, Sci. Total Environ., 565, 1165-1174, 2016b.

Romkens, M. J. M., Helming, K., and Prasad, S. N.: Soil erosion under different rainfall intensities, surface roughness and soil water regimes, Catena, 46, 103-123, 2001.

Sadeghi, S. H. R., Gholami, L., Homaee, M., and Khaledi Darvishan, A.: Reducing sediment concentration and soil loss using organic and inorganic amendments at plot scale, Solid Earth, 6, 445-455, doi:10.5194/se-6-445-2015, 2015.

Selkimäki, M. and González-Olabarria, J. R.: Assessing Gully Erosion Occurrence in Forest Lands in Catalonia (Spain), Land Degrad. Dev., doi:10.1002/ldr.2533, 2016.

Tailong, G., Quanjiu, W. D., and Li, J. Z.: Effect of surface stone cover on sediment and solute transport on the slope of fallow land in the semi-arid loess region of northwestern China, J. Soil. Sediment., 10, 1200-1208, 2010.

Townend, J.: Practical statistics for environmental and biological scientists, Chichester, John Wiley and Sons, New York, USA, 2002.

Toy, T. J., Foster, G. R., and Renard, K. G.: Soil erosion: processes, prediction, measurement, and control, John Wiley and Sons, New York, USA, 2002.

Villarreal, M. L., Webb, R. H., Norman, L. M., Psillas, J. L., Rosenberg, A. S., Carmichael, S., Petrakis, R. E., and Sparks, P. E.: Modeling Landscape-scale Erosion Potential Related to Vehicle Disturbances Along the USA-Mexico Border, Land Degrad. Dev., 27, 1106-1121, 2016.

Zhang, K., Zheng, H., Chen, F. L., Ouyang, Z. Y., Wang, Y., Wu, Y. F., Lan, J., Fu, M., and Xiang, X. W.: Changes in soil quality after converting Pinus to Eucalyptus plantations in southern China, Solid Earth, 6, 115-123, doi:10.5194/se-6-115-2015, 2015.

Zhao, G., Mu, X., Jiao, J., An, Z., Klik, A., Wang, F., Jiao, F., Yue, X., Gao, P., and Sun, W.: Evidence and Causes of Spatiotemporal Changes in Runoff and Sediment Yield on the Chinese Loess Plateau, Land Degrad. Dev., doi:10.1002/ldr.2534, 2016. 